\title{
Kajian yuridis peraturan daerah mengenai larangan pengemis
}

\section{Nyimas Aziziah Jehan Yusaviera ${ }^{1}$, Holiyatul Farodis ${ }^{2}$, Yaris Adhial Fajrin ${ }^{3}$}

${ }^{1}$ Nyimas Aziziah Jehan Yusaviera; Fakultas Hukum Universitas Muhammadiyah Malang Jln. Raya Tlogomas, No. 246; Kota Malang; 65144; Indonesia; (0341)-460782.

2 Holiyatul Farodis; Fakultas Hukum Universitas Muhammadiyah Malang Jln. Raya Tlogomas, No. 246; Kota Malang; 65144; Indonesia; (0341)-460782.

${ }^{3}$ Yaris Adhial Fajrin; Fakultas Hukum Universitas Muhammadiyah Malang Jln. Raya Tlogomas, No. 246; Kota Malang; 65144; Indonesia; (0341)-460782.

\section{ART ICLEINFO}

Article history:

Received 2020-05-03

Received in revised form

2020-07-02

Accepted 2020-08-01

Kata kunci:

Kemiskinan; Pengemisan;

Perda Kota Malang No. 2 Tahun

2012.

\section{Keywords:}

Poverty; Beggars; Malang City

Regulation No. 2 of 2012.

\section{DOI:}

https://doi.org/10.26905/

idjch.v11i2.3640.

How to cite item:

Yusaviera, N., Farodis, H., E Fajrin, Y. (2020). Kajian yuridis peraturan daerah mengenai larangan pengemis. Jurnal Cakrawala Hukum, 11(2). doi:10.26905/idjch.v11i2.3640.

Corresponding Author:

* Nyimas Aziziah Jehan Yusaviera

E-mail address: jehansaviera19@gmail.com

\section{Abstrak}

Bertambahnya jumlah penyandang masalah kesejahteraan sosial menjadi hal yang mendapat perhatian serius dari pemerintah. Penyandang masalah kesejahteraan sosial tersebut mayoritas dikarenakan oleh kemiskinan. pola pemikiran dari pengemis terdapat pula pola pikir dari masyarakat, sering kali masyarakat ketika melihat pengemis selalu merasa kasihan dan iba. Sudah banyak langkah yang telah Pemerintah tempuh, salah satunya adalah pada pemberlakuan peraturan perundangundangan yang mengatur terkait larangan untuk mengemis di muka umum. Penulisan ini metode yang di adalah dengan menggunakan metode normatif, yaitu penelitian yang berfokus pada kajian dalam penerapan suatu kaidah atau norma dalam hukum positif. Faktor yang menjadi alasan mengatakan Peraturan Daerah (Perda) Kota Malang Nomor 2 tahun 2012 Tentang Ketertiban Umum dan Lingkungan masih menimbulkan ketidak efektivitasan regulasi. Langkah tersebut betujuan untuk mengatasi pengemisan di muka umum yang dapat mengganggu ketertiban umum. Peraturan perundang-undangan yang dikeluarkan oleh Pemerintah Kota Malang untuk menanggulangi permasalahan social tersebut adalah Peraturan Daerah Kota Malang Nomor 2 Tahun 2012 tentang Ketertiban Umum dan Lingkungan.

\begin{abstract}
The increasing number of people with social welfare problems has received serious attention from the government. The majority of people with social welfare problems are due to poverty. The mindset of beggars is also the mindset of the community, often when people see beggars they always feel sorry and pity. The government has taken many steps, one of which is the enforcement of laws and regulations regarding the prohibition of begging in public. This writing method is to use the normative
\end{abstract}




\section{Kajian yuridis peraturan daerah mengenai larangan pengemis \\ Nyimas Aziziah Jehan Yusaviera, Holiyatul Farodis, Yaris Adhial Fajrin}

method, namely research that focuses on the study of the application of a rule or norm in positive law. The reason for this is that the Regional Regulation (Perda) of Malang City Number 2 of 2012 concerning Public Order and the Environment still creates regulatory ineffectiveness. This step aims to overcome public begging which can disrupt public order. The statutory regulations issued by the Malang City Government to overcome these social problems are the Malang City Regional Regulation Number 2 of 2012 concerning Public Order and the Environment.

\section{LatarBelakang}

Indonesia sebagai negara yang berkembang masih menghadapi tantangan terkait kemiskinan, hal ini terjadi karena negara Indonesia masih memiliki pendapatan yang rendah, pembangunan insfrastuktur yang terbelakang dan sumber daya manusia yang perkembangannya masih kurang dibandingkan dengan global. Keberadaan masyarakat madani atau civil society dalam hubungan antara negara, masyarakat dan pasar berkembang sangat pesat disertai oleh gelombang globalisasi yang mempengarui perikehidupan seluruh umat manusia. (Muslimin, 2016)

Hal inilah yang menyebabkan negara Indonesia masih terus menghadapi masalah kemiskinan, kemiskinan terjadi di berbagai wilayah di Indonesia baik di dikota-kota besar maupun di daerahdaerah pelosok. Di Provinsi Jawa Timur, khususnya Kota Malang, pada tahun 2019 pensentase penduduk miskin sebanyak $4.07 \%$, persentase tersebut menunjukan bahwa pada tahun 2019 kemiskinan di Kota Malang mengalami penurunan sebesar 1\%, dimana pada tahun 2018 sebelumnya persentase penduduk miskin di Kota Malang adalah sebesar 4.17\%. Namun, meskipun persentase penduduk miskin di Kota Malang mengalami penurunan, garis kemisinan di Kota Malang adalah sebesar 543.966 (Rp/Kapita/Bulan). Garis kemiskinan tersebut lebih banyak dibandingkan pada tahun 2018 yang sebesar 507.144 (Rp/Kapita/Bulan). Persentase Indeks Kedalaman Kemiskinan di Kota Malang pada tahun 2019 adalah sebesar 0.55\%, angka ini sama dengan pada tahun 2018. Sedang- kan persentase Indeks Keparahan Kemiskinan pada tahun 2019 di Kota Malang adalah sebesar 0.13\%, jika dibandingkan pada tahun 2018 persentase tersebut mengalami kenaikan dimana pada tahun 2018 Indeks Keparahan Kemiskinan Kota Malang adalah sebesar $0.11 \%$ (BPS Kota Malang, 2020).

Banyak faktor penyebab kemiskinan seperti halnya bertambahnya penduduk yang tidak di imbangi dengan tersedianya lapangan pekerjaan, pembangunan yang tidak merata antara di kota dengan di daerah-daerah pelosok yang berdampak terhadap sulitnya mendapatkan akses pendidikan sehingga banyak dari mereka tidak mempunyai bekal pendidikan dan keterampilan yang memadai sehingga sulit untuk mendapatkan akses pekerjaan, yang mengakibatkan mereka melakukan pekerjaan apapun untuk mencukupi kebutuhan hidup termasuk dengan cara mengemis atau meminta-minta.

Pemerintah dan lembaga non-pemerintahan telah mengupayakan banyak cara demi mengatasi permasalahan sosial yang menjadi suatu akibat dari maraknya pengemisan di muka umum, seperti mengadakan program transmigrasi penduduk ke daerah-daerah yang kurang padat atau masih jarang penduduknya. Dan untuk menanggulangi meningkatnya jumlah penduduk pemerintah juga mengadakan program Keluarga Berencana (KB). Akan tetapi upaya-upaya yang di lakukan oleh pemerintah maupun lemabaga non pemerintah tersebut masih belum berhasil. Karena jika di lihat pada kenyataan yang terjadi di lapangan fenomena pengemisan tersebut tidak berkurang, tetapi semakin meningkat. (Priambodo, 2019). 


\section{Jurnal Cakrawala Hukum, Volume 11 No. 2 Agustus 2020}

ISSN PRINT 2356-4962 ISSN ONLINE 2598-6538

Langkah-langkah yang saat ini sudah pemerintah tempuh salah satunya dapat dilihat pada pemberlakuan peraturan perundang-undangan yang mengatur terkait larangan untuk mengemis di muka umum. Hukum dan masyarakat merupakan dua entitas yang berbeda. Keduanya memiliki peran dan fungsi masing-masing dalam kehidupan. Akan tetapi keduanya tidak bisa dipisahkan satu sama lain, karena keduanya saling membutuhkan. Keberadaan hukum juga membutuhkan keberadaan masyarakat. (Mushafi, 2018)

Langkah tersebut betujuan untuk mengatasi dan menanggulangi maraknya pengemisan di muka umum yang dapat mengganggu ketertiban umum. Kota Malang merupakan salah satu pemerintah daerah yang memberikan perhatian terhadap permasalahan pengemisan di muka umum melalui pembentukan Peraturan Daerah Kota Malang Nomor 2 Tahun 2012 tentang Ketertiban Umum Dan Lingkungan. Secara spesifik larangan pengemisan termaktub dalam Pasal 13 ayat (1) yang berbunyi:

Setiap orang dilarang melakukan pekerjaan untuk mendapat penghasilan dengan meminta-mintal mengemis di muka umum baik di jalan, taman, tempat-tempat lain dengan berbagai cara dan alasan untuk mengharapkan belaskasihan dari orang lain;

dalam peraturan tersebut sudah sangat jelas bahwa semua orang dilarang untuk melakukan pekerjaan dengan cara meminta-minta atau mengemis di muka umum khususnya di wilayah Kota Malang, akan tetapi fakta yang terjadi saat ini masih banyak pengemis yang melakukan aksinya di wiliyah Kota Malang. Merujuk pada data PMKS Dinas Sosial Kota Malang tahun 2016 pengemis di Kota Malang, pada jenis kelamin lakilaki sebanyak 32 jiwa penduduk dan pada jenis kelamin perempuan adalah sebanyak 39 jiwa penduduk, maka jika di totalkan pengemis pada tahun 2016 mencapai angka 71 jiwa penduduk. Ditahun berikutnya angka tersebut naik mencapai 158 jiwa penduduk, dimana pada jenis kelamin lakilaki sebanyak 70 jiwa dan pada jenis kelamin perempuan adalah sebanyak 88 jiwa. (Dinas Sosial Kota Malang, 2019) Menjadi catatan penting karena eksistensi regulasi terkait larangan pengemisan tidak mampu menanggulangi pengemisan yang terjadi di kota Malang.

Fakta tersebut menjadi isu penting dalam tulisan ini terkait efektivitas regulasi ditinjau dari teori efektivitas hukum dari Lawrance Friedman. Dikarenakan banyak faktor yang menjadi alasan mengatakan Peraturan Daerah (Perda) Kota Malang Nomor 2 tahun 2012 Tentang Ketertiban Umum dan Lingkungan masih menimbulkan ketidak efektivitasan regulasi sehingga menimbulkan permasalahan diantaranya bagaimana efektivitasPasal 13 Perda Kota Malang Nomor 2 tahun 2012 Ketertiban Umum dan Lingkungan terkait pengemisan di muka umum, serta apa saja faktor penghambat dalam penerapan Pasal 13 Perda Kota Malang Nomor 2 tahun 2012 Ketertiban Umum dan Lingkungan terkait pengemisan di mukaumum.

\section{Metode}

Dalam penulisan ini metode yang di adalah dengan menggunakan metode normatif, yaitu penelitian yang berfokus pada kajian dalam penerapan suatu kaidah atau norma dalam hukum positif.

Pada penulisan ini data yang digunakan adalah data sekunder, yaitu terkait pada perturan perundang-undangan, buku, jurnal, kepustakaan, dan makalah terkait pengemisan, serta sumber lain yang diperlukan dalam penulisan ini.

\section{Pembahasan}

\subsection{Efektifitas Pasal 13 Ayat (1) Peraturan Daerah Kota Malang Nomor 2 Tahun 2012 Mengenai Pengemisan Di Mukaumum}

\section{A. Menguji efektivitas Hukum dalam Pelaksanaan}

Sebelum jauh masuk pada diskursus efektivitas hukum perlu di perjelas bahwasannya 


\section{Kajian yuridis peraturan daerah mengenai larangan pengemis}

Nyimas Aziziah Jehan Yusaviera, Holiyatul Farodis, Yaris Adhial Fajrin

menguji efektivitas hukum bukanlah murni diskursus terkait dogmatic hukum. (Yudho dan Tjandrasari, 2019), pembahasan masalah efektivitas hukum yang berada diluar dogmatic hukum menciptakan pola hubungan timbal balik antara ilmu hukum dan sosiologi hukum. Lawrance Friedman memberikan patokan menguji efektivitas hukum. Menurut Friedman terdapat 3 (tiga) unsur utama dari sistem hukum (legal system), yaitu (Yansen, 2019): 1) Legal Structure, 2) Legal Substance, 3) Legal Culture.

Lawrence M. Friedman menyatakan bahwa suatu penegakan hukum dapat dikatakan efektif atau berhasilnya tidaknya tergantung pada 3 (tiga) unsur sistem hukum di atas. Keberadaan tiga patokan dari Freidman memiliki peranan menguji dan memastikan terjadi singkronisasi antara regulasi dengan struktur hukum, substansi hukum, dan budaya hukum. (Hermawanto, 2019)

Tujuan yang ingin di wujudkan oleh hukum adalah hukum itu digunakan untuk menghasilkan suatu perubahan dalam masyarakat atau sebagai alat rekayasa social. Demi terjaminnya fungsi hukum sebagai alat rekayasa sosial masyarakat agar lebih baik, maka yang di butuhkan tidak hanya ketersediaan hukum dalam arti hukum materiil atau peraturan, akan tetapi juga terdapat suatu jaminan atas perwujudan hukum materiil tersebut dalam praktek hukum atau adanya penegakkan hukum (law enforcement)yang baik (Fuady, 2003). Suatu hukum dapat bekerja bukan hanya karena peraturan perundang-undangannya saja, tetapi pada bagaimana aktifitas pelaksanaan dari lembaga penegakan hukumnya (Ali, 2002).

\section{a. Struktur Hukum (Legal Structure)}

Friedman menjelaskan berkaitan dengan struktur hukum"To begin with, the legal system has the structure of a legal system consist of elements of this kind: the number and size of courts; their jurisdiction...Structure also means how the legislature is organized ... what procedures the police department follow, and so on. Structure, in way, is a kind of cross section of the legal system... a kind of still photograph, with freezes the action." (Friedman, 2019)

Berdasarkan penjelasan dari Lawrence $\mathrm{M}$. Friedman tersebut, di dalam suatu struktur hukum harus mengandung beberapa unsure seperti jumlah dan tingkatan pengadilan, yuridiksi hakim, dan tata cara mengajukan banding dari pengadilan umum ke pengadilan tinggi. Struktur hukum juga merupakan penataan suatu badan legislative, langkah dan sikap yang harus dilakukan oleh badan eksekutif, dan etika dalam profesi yang harus ditaati oleh lembaga-lembaga seperti, kepolisian dan sebagainya. Jadi struktur hukum adalah lembaga hukum yang menjalankan tugas dari perangkat hukum yang ada. (Friedman, 2019) Ketika berbicara tentang struktur hukum di Indonesia, maka yang dapat dikategorikan termasuk dalam struktur hukum tersebut adalah lembaga-lembaga penegakan hukum seperti kepolisian, kejaksaan, dan kehakiman atau pengadilan. Sebagaimana dalam Pasal 31 ayat (4) Perda Kota Malang No. 2 Tahun 2012 tentang Ketertiiban Umum dan Lingkungan, disebutkan bahwa "Dalam pelaksanaan penertiban sebagaimana dimaksud pada ayat (1) dan ayat (3), Walikota dapat meminta bantuan aparat Kepolisian Negara Republik Indonesia". Selain itu, PPNS juga berwenang dalam melakukan penertiban maupun penyidikan ketertiban umum dan lingkungan sebagaimana diatur dalam Pasal 32 ayat (2) Perda Kota Malang No. 2 Tahun 2012 tentang Ketertiban Umum dan Lingkungan. Adapun yang dimaksud dengan PPNS adalah Penyidik Pegawai Negeri Sipil yang selanjutnya disingkat PPNS adalah Pejabat Pegawai Negeri Sipil tertentu di lingkungan Pemerintah Daerah yang diberi wewenang khusus oleh Undang-Undang untuk melakukan penyidikan terhadap pelanggaran yang berkenaan dengan tindak pidana dalam bidang ketertiban umum, kebersihan dan penataan Pedagang Kaki Lima (Pasal 


\section{Jurnal Cakrawala Hukum, Volume 11 No. 2 Agustus 2020}

ISSN PRINT 2356-4962 ISSN ONLINE 2598-6538

1 angka 21 Perda Kota Malang No. 2 Tahun 2012 tentang Ketertiban Umum dan Lingkungan).

b. Substansi Hukum (Legal Substance)

Pengertian dari substansi hukum meliputi: (1) Aturan, norma, dan pola perilaku orang dalam system hokum daerah tersebut; dan (2) Produk hukum yang dihasilkan oleh orang-orang yang berada di dalam system hukum tersebut berdasarkan keputusan yang mereka buat dan menerapkan aturan baru yang diperoleh dari keputusan itu. (Putra, 2017)

Mengenai Substansi Hukum, Friedman menjelaskan "Another aspect of the legal system is its substance. By this is meant the actual rules, norm, and behavioural patterns of people inside the system ...the stress here is on living law, not just rules in law books". Substansi hukum merupkan aspek lain yang terdapat di dalam sistem hukum. Adapun yang dimaksud dengan substansi tersebut adalah suatu aturan, norma, dan pola perilaku dalam diri manusia yang beradadalam suatu system. Dalam Substansi hukum di dalamnya menyangkut peraturan perundang-undangan yang berlaku dan memiliki kekuatan hukum mengikat yang menjadi pedoman bagi aparat penegak hukum.

Terkait legal substance dalam Perda Kota Malang No. 2 Tahun 2012 tentang Ketertiban Umum dan Lingkungan menurut analisa penulis masih terdapat kekurangan dikarenakan larangan untuk mengemis tidak diikuti dengan ancaman pidana seperti larangan perbuatan yang mengganggu ketertiban umum dan lingkungan lainnya. Pasal 33 Perda Kota Malang No. 2 Tahun 2012 tentang Ketertiban Umum dan Lingkungan tidak mengatur mengenai ketentuan ancaman pidana bagi pelaku pengemisan selain itu tidak adanya upaya pembinaan, hanya menekankan kepada penertiban dan pengawasan tidak menjadi solusi terhadap maraknya pengemisan di Kota Malang.

c. Budaya Hukum (Legal Culture)

Masalah budaya Hukum Friedman menjelaskan "The third component of legal system is legal culture. By this we mean people's attitudes toward law and legal system their belief... in other word, is the climate of social thought and social force which determines how law is used, avoided, or abused".

Budaya hukum adalah suatu tanggapan atau reaksi masyarakat terhadap hukum dan system hukumnya. Dengan kata lain, budaya hukum merupakan puncak dari pemikiran social masyarakat dan merupakan kekuatan sosial yang mengatur mengenai bagaimana hukum itu dapat dilakukan, dihindari, atau disalahgunakan. Walapun suatu penataan hukum telah tertata dan berjalan dengan baik, namun apabila substansi hukum dibuat tanpa adanya dukungan dari budaya hukum oleh masyarakat dan badan legislative yang berwenang dalam pembuatan suatu hukum, maka keefektifitasan dari penegakan hukum tidak berjalan dengan baik.

\section{B. Efektivitas Perda Kota Malang No. 2 Tahun 2012 tentang Ketertiban Umum dan Ling- kungan Kacamata Struktur Hukum Lawrance Friedman}

Peraturan Daerah Kota Malang Nomor 2 Tahun 2012 yang mengatur tentang Ketertiban Umum dan Lingkungan di undangkan pada tanggal 27 Juni 2012 dalam peraturan daerah tersebut terdapat Pasal 13 ayat (1) yang mengatur tentang larangan untuk melakukan pekerjaan dengan cara meminta-minta atau mengemis yang berbunyi :

"Setiap orang di larang melakukan pekerjaan untuk
mendapatkan penghasilan dengan meminta-mintal
mengemis di muka umum baik di jalan, taman dan
tempat-tempat lain dengan berbagai cara dan alasan
untuk mengharapkan belas kasihan dariorang lain".

Menurut uraian Pasal di atas, pengemis adalah setiap orang yang bekerja untuk memperoleh penghasilan, biasanya pekerjaan ini di lakukan dengan cara meminta-minta terutama di tempat 


\section{Kajian yuridis peraturan daerah mengenai larangan pengemis}

Nyimas Aziziah Jehan Yusaviera, Holiyatul Farodis, Yaris Adhial Fajrin

umum, dan pekerjaannya dilakukan untuk mendapatkan belas kasihan dari orang lain.

Peraturan Daerah ini di buat oleh Pemerintah Kota Malang dengan tujuan untuk mengefektifkan ketertiban umum dan keamanan lingkungan, karena masih banyak pengemis yang melakukan pekerjaan di muka umum dan membuat ketertiban umum menjadi terganggu. Sehingga Pasal 13 ayat (1) pada peraturan daerah ini mengatur mengenai larangan bagi semua orang agar tidak melakukan pekerjaan dengan cara mengemis atau memintaminta di tempat-tempat umum.

Larangan melakukan pekerjaan dengan cara mengemis yang di atur pada Pasal 13 ayat (1) ini sudah relevan agar tidak ada masyarakat yang melakukan pekerjaan tersebut. Akan tetapi jika di lihat fakta yang terjadi sampai saat ini masyarakat tidak mematuhi larangan pada Pasal tersebut dan masih banyak masyarakat yang melakukan pekerjaan tersebut. Lokasi para pengemis tersebut beroperasi dapat berubah atau berpindah-pindah, namun pengemisan tersebut banyak terlihat di daerah sekitar Jembatan Soekarno-Hatta depan Universitas Brawijaya, di depan ATM Gedung Vokasi Universitas Brawijaya, di persimpangan arah Jalan Gajayana, dan beberapa persimpangan di Malang lainnya.

Kurangnya pengaturan tentang sanksi yang akan di berikan terhadap orang-orang yang melanggar menjadi faktor penyebab masyarakat tidak patuh pada Pasal tersebut. Beberapa faktor lain seperti kurangnya pengetahuan masyarakat terhadap Peraturan Daerah ini khususnya terkait larangan mengemis yang di atur pada Pasal 13 ayat (1) dan tingginya angka kemiskinan di Kota Malang membuat masyarakat tidak mematuhi larangan pada Pasal tersebut. Ketentuan pidana pada Perda Kota Malang No. 2 Tahun 2012 tentang Ketertiban Umum dan Lingkungan yang diatur didalam Pasal 33, berbunyi: Setiap orang atau badan yang melanggar ketentuan Pasal 4, Pasal 5, Pasal 21 dan Pasal 22 diancam dengan pidana kurungan paling lama 3 (tiga) bulan dan/atau denda paling banyak Rp.10.000.000,00 (sepuluh juta rupiah). Setiap orang atau badan yang melanggar ketentuan Pasal 6, Pasal 7, Pasal 9, Pasal 10, Pasal 11, Pasal 16 dan Pasal 18 diancam dengan pidana kurungan paling lama 3 (tiga) hari dan/atau denda paling banyak Rp. 100.000,00 (seratus ribu rupiah).

Tidak dirumuskannya sanksi atau ancaman pidana tersebut pada Pasal 13 menyebabkan masalah kepengemisan di Kota Malang tidak kunjung usai.

Ditinjau dari sudut legal culture, tingginya angka pengemis di Kota Malang dikarenakan kemiskinan. Kemiskinan menjadi salah satu alasan kenapa masih banyak masyarakat yang melakukan pekerjaan dengan cara mengemis dan beradasarkan data dari Dinas Sosial Kota Malang pada tahun 2017 jumlah pengemis di Kota Malang sebanyak 158 orang, dan dibedakan berdasarkan jenis kelamin, pengemis yang berjenis kelamin perempuan sebanyak 88 orang dan pengemis dengan jenis kelamin laki-laki sebanyak 70 orang. (Dinas Sosial Kota Malang, 2017) Dari data tersebut dapat di lihat bahwa meskipun Peraturan Daerah Nomor 2 tahun 2012 telah di undangkan pada 27 Juni 2012 akan tetapi sampai pada tahun 2017 masih banyak orang-orang yang melakukan pekerjaan dengan cara mengemis. Sehingga hal ini yang menjadi pernyataan apakah peraturan daerah tersebut efektif saat ini.

Jika mengacu pada teori Friedman tentang sistem hukum dalam suatu penegakan hukum dapat efektif atau tidaknya, maka harus ada harmonisasi dari 3 (tiga) elemen strukutur Hukum, Substansi Hukum, dan Budaya Hukum. Jika di lihat larangan mengemis di Muka Umum secara Substansi sudah di atur di dalam Pasal 13 ayat (1) Peraturan Daerah Kota Malang Nomor 2 Tahun 2012, dan mengenai penegakan terhadap Peraturan tersebut sudah di atur dalam Pasal 13 ayat (2) dan Pasal 32. Akan tetapi tingkat kepatuhan masya- rakat Kota Malang terhadap hukum masih kurang 
sehingga banyak terjadi pelanggaran terhadap ketentuan dalam Pasal 13 ayat (1) dan hal tersebut mengakibatkan penegakan hukum tidak berjalan maksimal.

Jika melihat pada fakta-fakta yang terjadi saat ini dan di kaitkan dengan teori sistem hukum dari Friedman maka dapat di simpulkan bahwa Peraturan Daerah Kota Malang Nomor 2 Tahun 2012 khususnya untuk penerapan Pasal 13 ayat (1) masih belum efektif karena masih banyak masyarakat yang melakukan pekerjaan dengan cara mengemis dan berusaha untuk mendapatkan penghasilan dari belas kasihan orang lain dan pengemis ini masih banyak kita temui di tempat-tempat umum.

\subsection{Faktor Penghambat Dalam Penerapan Pasal 13 Peraturan Daerah Kota Malang terkait Pengemisan di Mukaumum.}

Dalam suatu peraturan terdapat faktor-faktor yang menjadi suatu penghambat dalam penerapan atau pelaksanaannya sehingga peraturan tersebut masih belum efektif atau kurang efektif. Berikut ini beberapa faktor yang menjadi penghambat dalam penerapan Pasal 13 ayat (1) Peraturan Daerah Kota Malang.

\section{A. Peraturan Hukum}

Perturan hukum terkait pengemisan di muka umum di Kota Malang masih jauh dari kata sempurna karena peraturan terkait dengan larangan pengemisan di muka umum masih digabungkan dengan peraturan-peraturan lain dalam Perda Kota Malang mengenai ketertiban umum. Selain hal tersebut dalam Perda Kota Malang yang mengatur mengenai larangan mengemis di muka umum tersebut masih tidak tegas mengatur mengenai sanksi yang diberikan baik kepada orang-orang yang melakukan pekerjaan dengan cara meminta-minta atau pengemis maupun kepada orang-orang yang memberikan bantuan kepada pengemis, karena orang-orang yang memberikan bantuan kepada pengemis juga menjadi salah satu penyebab masih banyaknya orang-orang mengemis di Kota Malang.

Pasal 13 ayat (1)Perda Kota Malang No. 2 Tahun 2012 tentang Ketertiban Umum dan Lingkungan menyatakan bahwa: "Setiap orang dilarang melakukan pekerjaan untuk mendapat penghasilan dengan meminta-minta/mengemis di muka umum baik di jalan, taman dan tempat-tempat lain dengan berbagai cara dan alasan untuk mengharapkan belas kasihan dari orang lain". Berdasarkan pasal tersebut sudah jelas bahwa setiap orang dilarang untuk melakukan pengemisan, namun pada kenyataannya masih ditemukan pengemis di jalan maupun ditempat umum lainnya. Didalam Pasal 14 dikatakan bahwa masyarakat dapat melakukan pelaporan apabila ditemukan suatu pelanggaran terhadap ketertiban umum dan lingkungan kepada pihak-pihak yang berwenang, dari situ dapat diketahui bahwa masyarakat juga memiliki peran serta dalam menjaga ketertiban umum dan lingkungan. Jika kesadaran hukum masyarakat akan peraturan ini masih kurang, sehingga peraturan hukum yang telah ada dinilai tidak berjalan secara efektif dan dapat mengakibatkan pengemisan di Kota Malang masih terus bermunculan.

\section{B. Pola Pemikiran}

Pola pemikiran pengemis yang tidak mau susah dalam bekerja menjadi faktor penghambat penerapan Pasal 13 ayat (1) Peraturan Daerah Kota Malang, menurut pengemis pekerjaan mengemis itu sangat mudah dan menghasilkan penghasilan yang lebih besar dari pada menjadi seorang pegawai ataupun seorang buruh. Dari pola pemikiran pengemis tersebut terdapat budaya malas yang sudah melekat dalam diri pengemis, seorang pengemis hanya mengandalkan belas kasihan orang lain dengan cara meminta-minta, ia tidak mau bersusah payah untuk bekerja keras demi mendapatkan uang. 


\section{Kajian yuridis peraturan daerah mengenai larangan pengemis}

Nyimas Aziziah Jehan Yusaviera, Holiyatul Farodis, Yaris Adhial Fajrin

\section{Kemiskinan}

Mayoritas orang memilih menjadi seorang pengemis adalah karena orang-orang tersebut tidak mampu menghadapi suatu permasalahan perekonomian yang berkelanjutan. Tingginya angka kemiskinan yang saat ini masih di alami oleh beberapa masyarakat menjadi salah satu faktor pekerjaan mengemis tetap bertahan dan terus bertambah. Meskipun angka kemiskinan di Kota Malang telah megalami penurunan hingga 4.10\% pada tahun 2018, (BPS Kota Malang, 2018) namun hal tersebut tidak membuat pengemis di Kota Malang menjadi jarang terlihat.

Adapun kemiskinan yang diakibatkan adanya kultur sosial dan struktur sosial yang menyebabkan salah satunya adalah terjadinya suatu pengemisan didalam suatu daerah. Kemiskinan dalam kultur social timbul karena adanya rasa pesimis, alias penyakit simiskin. Boros, mementingkan hal yang bersifat aksesoris, keinginan untuk pamer, tidak mempunyai harga diri, malas, menunda waktu, tidak punya kepedulian kepada hal lain merupakan contoh dari pesimis. Sedangkan kemiskinan secara struktur social adalah situasi dimana kemiskinan timbul sebagai akibat dari rendahnya akses terhadap sumberdaya yang terjadi dalam suatu sistem sosial budaya dan social politik yang tidak mendukung kemiskinan, tetapi sering kali menyebabkan kemiskinan menjadi subur. (Ihsan, 2017)

Salah satu contoh pengemisan yang timbul akibat kultur social dan struktur sosial dapat dilihat di daerah Desa Pragan Raya, Kabupaten Sumenep, Madura. Masyarakat disana memiliki kesadaran bahwa mereka tidak akan mungkin mendapatkan apa yang mereka inginkan kecuali dengan cara yang telah diturunan oleh nenek moyang mereka, yaitu mengemis. Mereka berpikir bahwa mengemis adalah pekerjaan yang mulia dan merupakan ibadah, karena salah satu tujuannnya adalah untuk mensucikan harta orang yang berekonomi tinggi. Mereka juga berpikir bahwa mengemis lebih mulia dibanding jika harus mencuri. Pemahaman tersebut dibangun di lingkungan kampung pengemis bahwa tindakan mengemis lebih mulia dibanding kan jika harus melakukan suatu pencurian. (Mahfudz, 2018)

\section{Malas Bekerja}

Lapangan pekerjaan yang sedikit menjadi salah satu faktor banyak orang yang memilih bekerja dengan cara meminta-minta/mengemis. Faktor malas bekerja di sini juga di pengaruhi oleh pola pemikiran, banyak dari pengemis yang berpikir bahwa pekerjaan mengemis itu sangat mudah dan tidak perlu bersusah payah seperti pekerjaan pada umumnya yang butuh tenaga lebih besar. (BPS Kota MalangTahun 2018) Dengan pola pemikiran seperti ini yang menimbulkan rasa malas untuk bekerja yang lebih layak.

\section{E. Pengemis yang Datang dari Luar Kota Malang}

Sebagai kota yang besar dan memiliki banyak penduduk, Kota Malang menjadi suatu magnet bagi orang-orang yang ingin mencari peruntungan di kota ini, sama halnya dengan beberapa pengemis yang datang dari berbagai kota untuk mencari penghasilan di Kota Malang. Pengemis tersebut di dominasi oleh penduduk yang berdomisili sekitaran luar Kota Malang atau daerah yang didekat Kota Malang. Kedatangan pengemis dari luar Kota Malang tersebut juga menjadi salah satu faktor yang menghambat dalam menerapkan Peraturan Daerah mengenai pengemis ini.

\section{Kesimpulan}

Di dalam Kitab Undang-Undang Hukum Pidana (KUHP) pengemisan sudah di atur dalam Pasal 504 buku ke III dan di kualifikasikan sebagai delik Pelanggaran terhadap ketertiban umum. Akan tetapi Kota Malang mengatur lebih khusus terkait dengan larangan melakukan pekerjaan dengan cara meminta-minta atau mengemis hal ini tercantum dalam Peraturan Daerah Kota Malang 


\section{Jurnal Cakrawala Hukum, Volume 11 No. 2 Agustus 2020}

ISSN PRINT 2356-4962 ISSN ONLINE 2598-6538

Nomor 2 Tahun 2012 tentang Ketertiban Umum dan Lingkungan khusunya Pasal 13 ayat (1).

Seiring berjalannya waktu Pasal 13 ayat (1) PERDA Nomor 2 Tahun 2012 dalam penerapannya masih kurang efektif karena masih banyak masyarakat yang mencari penghasilan dengan cara melakukan pekerjaan mengemis atau memintaminta. Pengemis di Kota Malang masih banyak kita temui di tempat-tempat umum seperti di jalan, lingkungan kampus, pusat pembelanjaan dan tempat-tempat wisata.

Terdapat beberapa faktor yang menjadi penghambat penerapan Pasal 13 ayat (1) PERDANomor 2 Tahun 2012 seperti faktor kemiskinan, pola pemikiran dari masyarakat dan pengemis itu sendiri, serta banyaknya pengemis dari luar kota yang mengadu peruntungan ke Kota Malang.

\section{Daftar pustaka}

Ali, Achmad. 2002. Keterpurukan Hukum di Indonesia. Jakarta. Ghalia Indonesia.

Badan Pusat Statistik Kota Malang. Jumlah Penduduk Miskin Kota Malang. Diakses dari https:// malangkota.bps.go.id/pada tanggal 24 November 2019.

Badan Pusat Statistik Kota Malang. Persentase Penduduk Miskin, Jumlah Penduduk Miskin, Garis Kemiskinan, Indeks Kedalaman Kemiskinan, dan Indeks Keparahan Kemiskinan Kota Malang. Diakses dari https:// malangkota.bps.go.id/ pada tanggal 16 Januari 2020.

Data Dinamis Provinsi Jawa Timur Triwulan II Tahun 2018, diakses dari http://jatimprov.go.id/ppid/ uploads/berkasppid/dinamis_2_2018.pdf pada tanggal 18 Januari 2020.

Dinas Sosial Kota Malang. Rekapitulasi Penyandang Masalah Kesejahteraan Sosial Tahun 2017 Kota Malang. Diakses dari https://dinsos. malangkota.go.id/data-pmks/pada tanggal 30 November 2019.

Fuady, Munir. 2003. Aliran Hukum Kritis: Paradigma Ketidakberdayaan Hukum. Bandung. Citra Aditya Bakti.
Hermawanto, Kurniawan, dkk. Teori Sistem Hukum Lawrence M. Friedman. Diakses dari https:// www.academia.edu/ pada tanggal 8 Desember 2019.

Ihsan, Muhammad. 2017. Pengentasan Kemiskinan Melalui Pemberdayaan Ekonomi Umat Menurut Perspektif Islam. Al-Falah: Journal of Islamic Economics. Vol. 2, No. 1.

Mahfudz, Misdar. 2018. Konstruksi Budaya Mengemis Pada Masyarakat Desa Pragaan Daya Kecamatan Pragaan Kabupaten Sumenep Madura. Universitas Airlangga.

Moeljatno. Kitab Undang-Undang Hukum Pidana. Jakarta. Bumi Aksara.

Mushafi, M., \& Marzuki, I. (2018). Persinggungan Hukum dengan Masyarakat dalam Kajian Sosiologi Hukum. Jurnal Cakrawala Hukum, 9(1), 50-58. doi:10.26905/idjch.v9i1.2168.

Muslimin, H. (2016). Tantangan terhadap pancasila sebagai ideologi dan dasar negara pasca reformasi. Jurnal Cakrawala Hukum, 7(1), 30-38. doi:10.26905/idjch.v7i1.1791.

Peraturan Daerah Kota Malang Nomor 2 Tahun2012 tentang Ketertiban Umum dan Lingkugan.

Priambodo, Arie Novisatrio. 2017. Pelaksanaan Pasal 13 Peraturan Daerah Kota Malang Nomor 2 Tahun 2012 Tentang Ketertiban Umum Dan Lingkungan Terkait Pengemis Yang Meminta-Minta Ditempat Umum (Studi Di Wilayah Hukum Kota Malang).

Putra, Jaka Raya Andika. 2017. Tanggung Jawab Hukum Kepolisian Terhadap Barang Sitaan Dalam Perkara Lalu Lintas Yang Berupa Kendaraan Bermotor (Studi di Satlantas Polres Kota Batu). Skripsi. Universitas Muhammadiyah Malang.

Soekanto, Soerjono. 1983. Faktor-Faktor Yang Mempengaruhi Penegakan Hukum. Jakarta. Rajawali.

Yansen, Jimmy, Penerapan Norma Hukum Dalam Sistem Peradilan di Indonesia, tanpa tahun https:// www.academia.edu/37265637/Teori_sistem_ hukum, diakses tanggal 20 Desember 2019.

Yudho, Winarno dan Heri Tjandrasari, Efektivitas Hukum Dalam Masyarakat. Jurnal Hukum dan Pembangunan, Vol 17 No 1. 